\title{
Faunal diversity across a sandy shore
}

\author{
Werner Armonies*, Karsten Reise
}

Alfred Wegener Institute Foundation, Biologische Anstalt Helgoland, Wattenmeerstation Sylt, 25992 List, Germany

\begin{abstract}
At a sandy beach site on the island of Sylt in the North Sea, the interstitial micro- and meiofauna has been studied by several investigators since the 1960s, and a total of 652 species living between the tide marks has been reported. Most of the effort was devoted to the free-living Plathelminthes ('Turbellaria'), which accounted for $32 \%$ of all species, followed by Nematoda (27\%), Ciliata (11\%, the smallest size-groups not included), Copepoda $(10 \%)$, Gastrotricha (7\%), and 9 other major taxa. The species ratio of macrofauna to interstitial fauna was about $1: 25$ for the entire beach. The investigated shore consists of a steep upper slope from high to mid tide line $(13 \mathrm{~m})$, and a gentle lower slope from mid to low tide line (100 $\mathrm{m}$ horizontal distance). While the macrofauna gradually increased in species number from the beach face ( 8 species) towards low tide line ( 23 species), this was not the case for the diverse interstitial fauna. It attained a broad maximum of species richness at a $10 \mathrm{~m}$ wide terrace just below the steep slope of the beach face. Here an optimal balance may exist between organic supply, oxygen and water retention. Three hundred and fifty species per meter interval of the transect were recorded. From there species richness declined gradually towards the low tide line (230 species) and abruptly at the steep slope of the beach face (170 species). Similarity analysis indicates a threshold in species composition at the bend between the gentle and the steep slope, which is just above mid tide level. For marine interstitial fauna the mid shore provides a center of diversity.
\end{abstract}

KEY WORDS: Meiofauna $\cdot$ Macrofauna $\cdot$ Sandy beach $\cdot$ Diversity $\cdot$ North Sea $\cdot$ Intertidal

\section{INTRODUCTION}

With the recent concern about enhanced rates of species extinction caused by human activity, the need for a reliable estimate on the global number of species has become urgent (May 1988). In particular, studies on arthropods in the canopies of tropical trees have raised estimates of species on earth up to 30 million, of which less than 1.5 million have been described by taxonomists. Grassle \& Maciolek (1992) suggested that the species number of macrobenthic invertebrates in the deep sea may exceed 10 million. This estimate may be much too high (May 1992) but it serves as an example of the current lack of knowledge on biodiversity at the bottom of the sea (Committee on Biological Diversity in Marine Systems 1995, Snelgrove 1999).

Compared to the macrobenthic fauna, little is known about the diversity of the meiofauna (Metazoa passing a mesh width of $500 \mu \mathrm{m}$ ) and microfauna (Protozoa) of

\footnotetext{
•E-mail: warmonies@awi-bremerhaven.de
}

marine sediments (Giere 1993, Higgins \& Thiel 1988). According to Snelgrove et al. (1997), the meiofauna of marine sedimentary habitats comprise about 7000 species, while the projected number of species is estimated to be $10^{8}$. Such an estimate is essentially no more than an educated guess. Although the number of known macrofaunal species is much higher $(87000)$ than that of meiofauna, the projected number is 1 order of magnitude lower (Snelgrove et al. 1997). In order to make a sound estimate of marine benthic diversity and to provide an unbiased comparison with terrestrial diversity, we particularly need to improve our knowledge on the meio- and microfauna of marine sediments.

A complicating factor in the taxonomy of meiofauna is not only the minituarization of body size, often associated with structural simplification, but also the high percentage of morphologically similar or even identical species within related groups (Westheide 1991, Giere 1993). These may be ecologically divergent, but are not necessarily very distinct. Often, very similar congeneric species are found to coexist in the same 
habitat (Reise 1988) and i.e. exhibit only slight differences in prey choice (Menn \& Armonies 1999). As a consequence, the number of meiofaunal species at a particular site can only be obtained where diligent taxonomic and ecological research has been conducted.

The interstitial fauna of sandy beaches on the island of Sylt in the North Sea exhibits high phyletic and species diversity (Ax 1966, 1969). Why are there so many species adapted to dwelling in the interspaces of sand? To human perception, a sandy beach appears to be a rather homogeneous habitat, but this is not the case for small-sized interstitial organisms. Our study brings together a sequence of taxonomic and ecological surveys in which almost all major taxa of the interstitial fauna (meiofauna and microfauna) were investigated individually at the same site. This beach is now the type locality for 148 described species that are new to science. The surveys conducted over the last 30 yr have followed a similar scheme introduced by Schmidt (1968). This is a first attempt to integrate these data to produce an overview (1) of the total number of species and the relative contributions of the major taxa, and (2) of the spatial pattern of species richness along a transect from high to low tide line. To our knowledge there is no other beach site where the total number of species can be given at a similar level of completeness. This constitutes a first step toward reaching a more solid estimate of the number of meioand microfaunal species in marine sediments.

The second question concerns the distribution of species richness across the sandy shore between the tide marks. Benthic macrofauna generally increases in species density in the downshore direction, albeit with a short interruption at the breaking point of the waves (Brown \& McLachlan 1990). Does the same hold true for the smaller-sized fauna? We hypothesize that the duration of tidal emergence affects the interstitial fauna only in the steep slope of the beach which is swept by the tidal prism. At the more gentle sloping, lower part which remains saturated with marine water throughout the tidal cycle, tidal emergence ceases to be a key factor, and species richness shows no further increase in the downshore direction. If corroborated, this pattern will represent a distinct difference between meiofaunal and macrofaunal diversity, with the former being better buffered against the physical extremes of the seashore by dwelling in the interstitial system below the sediment surface throughout their entire life cycle.

\section{MATERIALS AND METHODS}

Site of investigation. The site is located on the sheltered side of the barrier island of Sylt in the east-

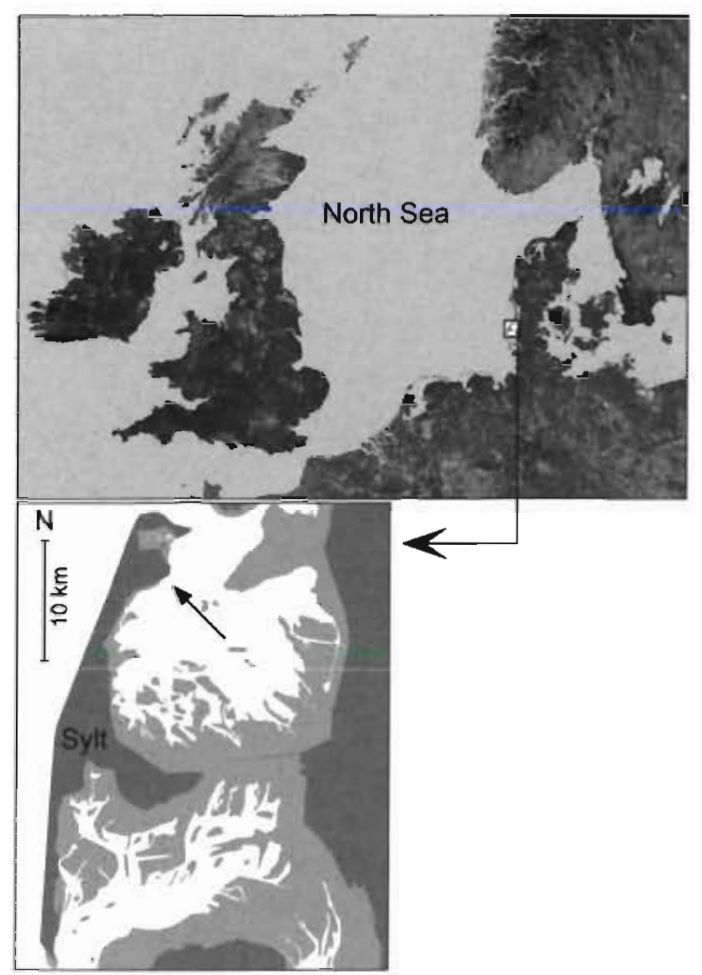

Fig. 1. Location of the study site. Light shading in the lower figure indicates tidal flats

ern North Sea, just south of List harbour (Fig. 1; $\left.55^{\circ} 5^{\prime} \mathrm{N}, 8^{\circ} 26^{\prime} \mathrm{E}\right)$. Wave height rarely exceeds $0.5 \mathrm{~m}$. The profile of this sandy shore consists of an upper part with a reflective beach face of $30 \mathrm{~m}$, and a lower one with a dissipative tidal flat of $100 \mathrm{~m}$ (Fig. 2). A general description is given by Schmidt (1968), Westheide (1968) and Hartwig (1973a). No apparent change in beach morphology, granulometry and hydrographic conditions has occurred over the past 25 yr. The beach face is convex in shape, with a lower slope of about 4 to $7^{\circ}$ inclination, depending on stormy and calm conditions, respectively. The bend between the steep beach face and the gentle flat has been designated the 0 mark of a transect running from mean high tide line $(-11$ to $-13 \mathrm{~m})$ to mean low $(+50 \mathrm{~m})$ and spring low tide line $(+75$ to $120 \mathrm{~m})$. Neap and spring tidal range are 1.55 and $1.95 \mathrm{~m}$, respectively. Mid tide level is close to the bend. The filling wedge or swept prism of the beach (see Brown \& McLachlan 1990) at mean high tide amounts to $4 \mathrm{~m}^{3} \mathrm{~m}^{-1}$, and may be up to $20 \mathrm{~m}^{3} \mathrm{~m}^{-1}$ during storm tides. Salinity in the overlying water is 30 to $32 \mathrm{psu}$, and conditions become brackish within the beach above mean high tide line.

Below the bend, a sand flat begins with a 10 to $12 \mathrm{~m}$ wide terrace, giving way to a shallow trough $(50 \mathrm{~m})$ 


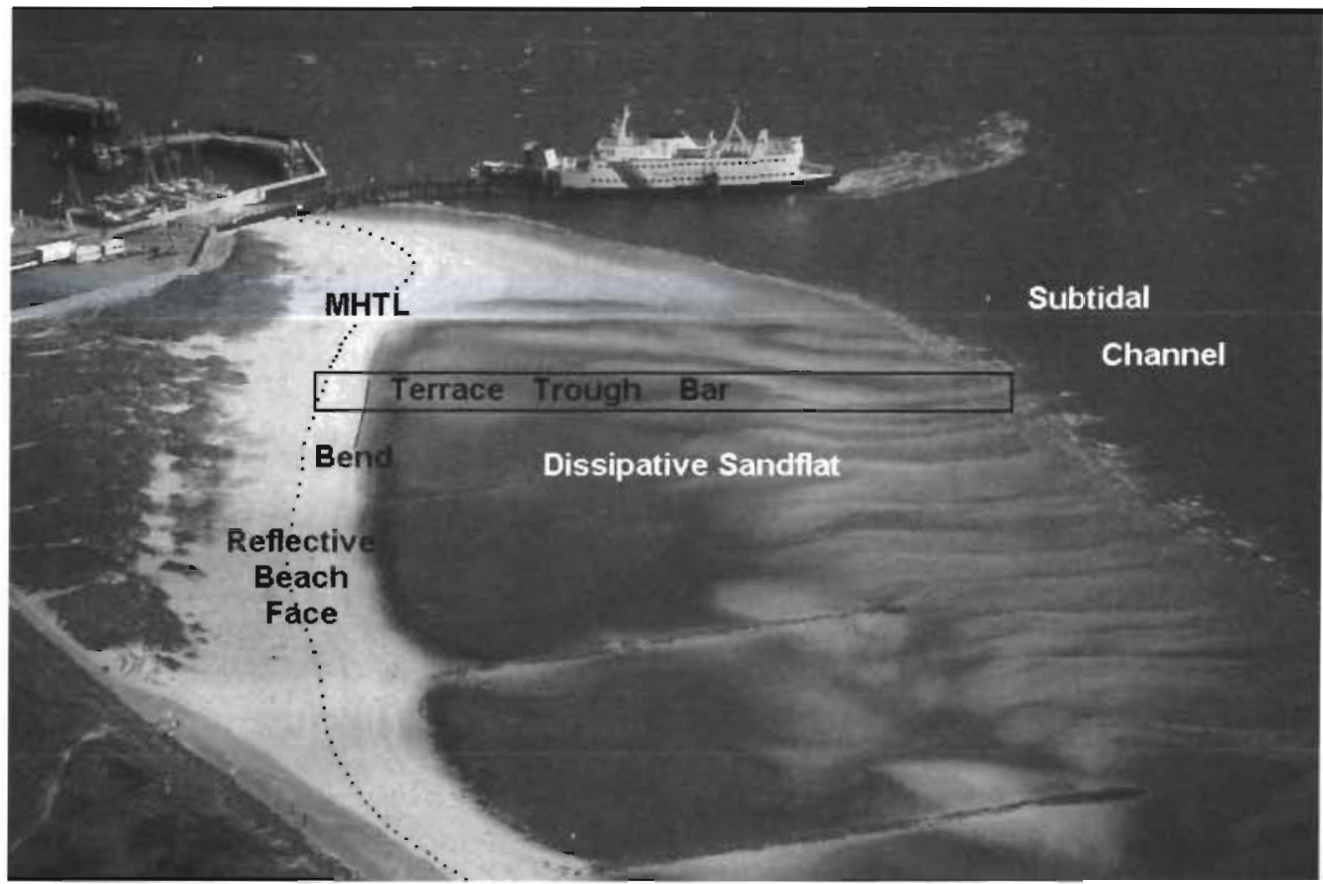

Fig. 2. Aerial photograph of the investigated beach at spring low tide, with dunes and the beach face on the left and the sand flat with terrace, trough and megaripples to the right. The sampled transect is indicated by a frame. The distance from mean high (MHTL) to spring low tide line is about $100 \mathrm{~m}$

and bar $(40 \mathrm{~m})$, both rippled and populated by the Iugworm Arenicola marina. Beyond low tide line there is another steep slope down to $24 \mathrm{~m}$ depth of a tidal channel with maximum current velocities of $1.2 \mathrm{~m} \mathrm{~s}^{-1}$. Mean water temperature is $5.3^{\circ} \mathrm{C}$ in winter and $13.7^{\circ} \mathrm{C}$ in summer. Median grain size of the quartz sand is $0.5 \mathrm{~mm}$ with little vertical or horizantal variation (Schmidt 1968). The sediment of the steep beach face and usually also of the terrace is devoid of a blackish sulfide layer, but it is a conspicuous feature in the trough and bar of the flat. It begins at 1 to $5 \mathrm{~cm}$ sediment depth in summer, and at 5 to $12 \mathrm{~cm}$ in winter. Organic content of the sediment varied from $0.1 \%$ in the beach face to $0.5 \%$ in the flat, and occasionally some higher values occurred close to low water level.

Sampling. The sampling procedure was described by Schmidt (1968) and Ax (1969), and subsequent investigators adhered to this scheme. Unreplicated samples were taken during low tide, and usually at $1 \mathrm{~m}$ intervals from mean high tide line at the beach down to the seaward end of the terrace. Above mean high tide level, only occasional samples were taken. Beyond the terrace, intervals were of 2 to $5 \mathrm{~m}$ until spring low tide line was reached. Sample tubes were dissected vertically into $5 \mathrm{~cm}$ intervals from the surface downwards and then 20 to $50 \mathrm{~cm}$ deep into the ground water zone at the beach. Samples above mean high water mark sometimes reached as deep as $2 \mathrm{~m}$ below the sediment surface. On the flat, vertical intervals were either 2 or $5 \mathrm{~cm}$, and sampling depth varied between 10 and $35 \mathrm{~cm}$. Sampling was performed at monthly intervals over an entire year for almost all of the major taxa.

Sample size was adapted to the expected abundance of the major taxon under study, ranging from 13.3 to $50 \mathrm{~cm}^{3}$ for each vertical interval. Altogether, about 50000 samples were obtained and $>1$ million individuals were counted and identified. Separation of interstitial fauna from sand was achieved by extraction with melting seawater-ice, a method invented by Uhlig (1964) and modified by Schmidt (1968) and Uhlig et al. (1973). Animals escaped from melting ice through a fine mesh, and accumulated in petri dishes underneath, which were then inspected under 10 to $50 \times$ magnification. For some taxa, in addition to this method, animals were washed out of the sediment by repeated shaking and decantation with seawater or freshwater. In nearly all cases, living specimens were obtained for further analysis. The various methods proposed for extracting interstitial fauna had strong effects on the quantities obtained (Higgins \& Thiel 1988, Giere 1993) but this is unlikely to have a strong effect on the species numbers reported here.

For comparison, the benthic macrofauna was sampled along the same transect in February 1975. Sediment cores $(\mathrm{n}=23)$ of $400 \mathrm{~cm}^{2}$ and $25 \mathrm{~cm}$ deep at the flat and up to $100 \mathrm{~cm}$ deep at the beach face were sieved through a $1 \mathrm{~mm}$ mesh. 


\section{RESULTS}

\section{Species richness}

From a sandy shore site along a transect between the tide marks a total of 652 species of interstitial fauna was obtained (Table 1). With 207 recorded species, the free-living Plathelminthes ('Turbellaria') were the most thoroughly investigated and comprised almost one third $(32 \%)$ of all species. Within the Plathelminthes, most species belonged to the Rhabdocoela (127: 'Typhloplanoida', 'Kalyptorhynchia', 'Dalyellioida'). Ehlers (1973) refers to more than 60 'Typhloplanoida' and about 30 'Dalyellioida'. This includes at least 29 more species which he observed but did not formally record.

The second most diverse taxon were the Nematoda $(27 \%)$, surveyed 4 times in 1973-74 with about 60000 individuals. Blome (1982) assumes that he encountered
$90 \%$ of the species present. Hartwig (1973b) suggests that there may have been some 30 more species of Ciliata than he described in his survey. Although almost all major taxa were investigated, no species were identified of the Flagellata (some 97 species according to M. Hoppenrath pers. comm.) and Foraminifera. Surveys of macrofaunal burrow structures were done on a sandy tidal flat adjacent to the transect site. From these about 30 more species may be added to the total (Reise \& Ax 1979, Reise 1984, 1987, Scherer 1985, Noldt \& Reise 1987, Sopott-Ehlers 1992, Wetzel et al. 1995, Wetzel 1997). Considering all minor omissions and shortcomings, about 200 species should be added to the recorded total.

The macrobenthic fauna of this site contained 28 species in a survey from February 1975. Westheide (1966) lists 3 additional macrofaunal polychaetes. Thus, the species ratio of macro- to meio-/microfauna is about $1: 25$.

Table 1. Species number of major taxa of the interstitial fauna recorded along a transect from high to low tide level at 1 sandy shore site, island of Sylt, North Sea

\begin{tabular}{|c|c|c|c|}
\hline \multicolumn{2}{|l|}{ Major taxon } & Species & Source \\
\hline \multicolumn{2}{|l|}{ Ciliata $^{a}$} & 72 & Hartwig $(1973 a, b)$ \\
\hline \multicolumn{2}{|l|}{ Cnidaria } & 1 & Schmidt (1969) \\
\hline \multicolumn{2}{|l|}{ Gnathostomulida } & 7 & Müller \& Ax (1971) \\
\hline \multirow[t]{8}{*}{ Plathelminthes ${ }^{b}$} & Catenulida & 2 & Faubel (1976a) \\
\hline & Acoelomorpha & 26 & Dörjes $(1968 a, b)$, Faubel $(1974 a, 1976 b, c)$ \\
\hline & Macrostomida & 12 & Pawlak (1969), Faubel (1974b, 1976b) \\
\hline & Prolecithophora & 2 & Armonies \& Hellwig-Armonies (1987) \\
\hline & Proseriata & 38 & $\begin{array}{l}\text { Sopott (1972, 1973), Armonies \& Hellwig-Armonies (1987), } \\
\text { Martens et al. (1989), Wellner \& Reise (1989) }\end{array}$ \\
\hline & Typhloplanoida & 48 & $\begin{array}{l}\text { Ax \& Heller (1970), Ax (1971), Ehlers }(1972,1973,1974), \\
\text { Ehlers et al. (1994) }\end{array}$ \\
\hline & Kalyptorhynchia & 66 & Ax \& Heller (1970), Schilke (1970), Hoxhold (1974) \\
\hline & Dalyellioida & 13 & $\begin{array}{l}\text { Ax (1970), Armonies \& Hellwig-Armonies (1987), Ehlers } \\
\text { (1973), Wellner \& Reise (1989) }\end{array}$ \\
\hline \multirow[t]{2}{*}{ Gastrotricha } & Macrodasyoidea & 23 & Schmidt \& Teuchert (1969), Potel \& Reise (1987) \\
\hline & Chaetonotoidea & 22 & Schmidt \& Teuchert (1969), Mock (1979) \\
\hline \multicolumn{2}{|l|}{ Rotatoria } & 16 & Tzschaschel $(1979,1980)$ \\
\hline \multicolumn{2}{|l|}{ Nematoda } & 179 & Blome $(1974,1982,1983)$ \\
\hline \multicolumn{2}{|l|}{ Nemertini } & 2 & $\operatorname{Mock}(1978,1981 a)$ \\
\hline \multicolumn{4}{|l|}{ Polychaeta ${ }^{c}$} \\
\hline \multicolumn{2}{|l|}{ 'Archiannelida') } & 18 & $\begin{array}{l}\text { Westheide (1965, 1966, 1967a,b,) Schmidt (1969, 1970), } \\
\text { Meineke \& Westheide (1979), Mock (1981b), Armonies \& } \\
\text { Hellwig-Armonies (1987) }\end{array}$ \\
\hline \multicolumn{2}{|l|}{ Oligochaeta } & 21 & $\begin{array}{l}\text { Kossmagk-Stephan (1983), Armonies \& Hellwig- } \\
\text { Armonies (1987) }\end{array}$ \\
\hline \multicolumn{2}{|l|}{ Tardigrada } & 2 & Schmidt (1969) \\
\hline \multicolumn{2}{|l|}{ Copepoda } & 64 & Mielke $(1973,1975,1976)$ \\
\hline \multicolumn{2}{|l|}{ Ostracoda } & 10 & Schmidt (1969), Scherner (unpubl) \\
\hline Acari & Halacarinae & 8 & Bartsch \& Schmidt (1979) \\
\hline
\end{tabular}




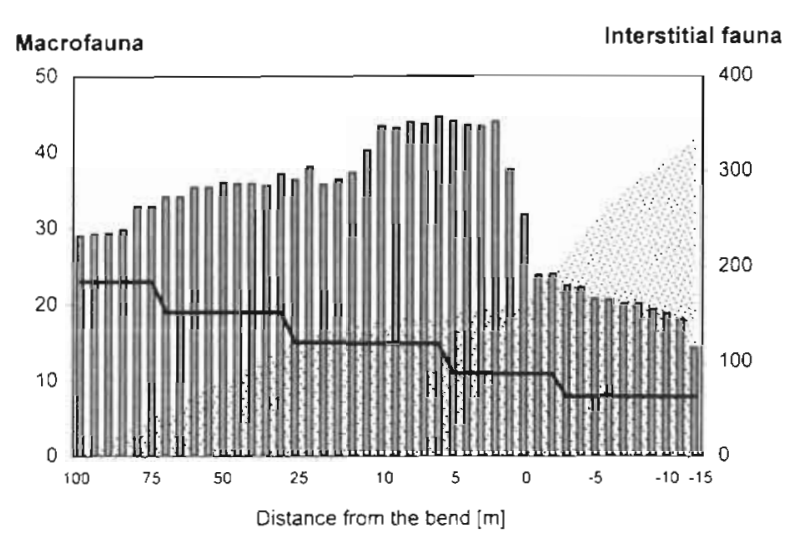

Fig. 3. Species richness of interstitial fauna (columns, right scale) and benthic macrofauna (bold line, left scale) along a transect from mean high to spring low tide level. Shading indicates the profile of the shore. Note that interval length is $1 \mathrm{~m}$ from $-10 \mathrm{~m}$ at the beach face to $10 \mathrm{~m}$ at the terrace, and increases to 2 and $5 \mathrm{~m}$ intervals towards high and Iow tide level

\section{Downshore gradient}

With regard to the distribution of species richness along the transect between the tide marks, the macrofauna gradually increased from high (8 species) to low tide line ( 23 species), while the interstitial fauna has a maximum at the terrace, i.e. the first 10 to $12 \mathrm{~m}$ of the gentle lower slope (Fig. 3). Here, approximately 350 species were recorded on every meter interval of the transect. The decline towards low tide level (230 species) was modest, while a threshold decline was appar- ent at the bend between the gentle and the steep slope of the beach (170 species).

This general pattern of species richness in the interstitial fauna is not a spurious result. The component major taxa show a similar trend (Fig. 4). None increased towards low tide line, and none had more species at the steep than the gentle slope. Similarly, within the well-studied Plathelminthes, the major subdivisions also adhered to this pattern (Fig. 5).

Calculated similarity in species composition of the total interstitial fauna, choosing selected intervals along the transect as a reference, also revealed a threshold at the bend between the gentle lower and the steep upper slope, while elsewhere similarity gradually decreased with distance (Fig. 6). This suggests that the interstitial fauna of this shore may be divided into 2 assemblages. The species richness curve of the Nematoda shows a slight increase at the uppermost end of the transect (Fig. 4). This indicates a transition to the brackish/terrestrial subterranean fauna. In general, however, sampling above high tide line was insufficient in most surveys to cover this faunal assemblage properly (see Ax \& Ax 1970).

\section{DISCUSSION}

\section{Number of species in the interstitial fauna}

We recorded 652 and estimate 850 species for the entire interstitial fauna at a particularly well-studied beach. The species number may be above average
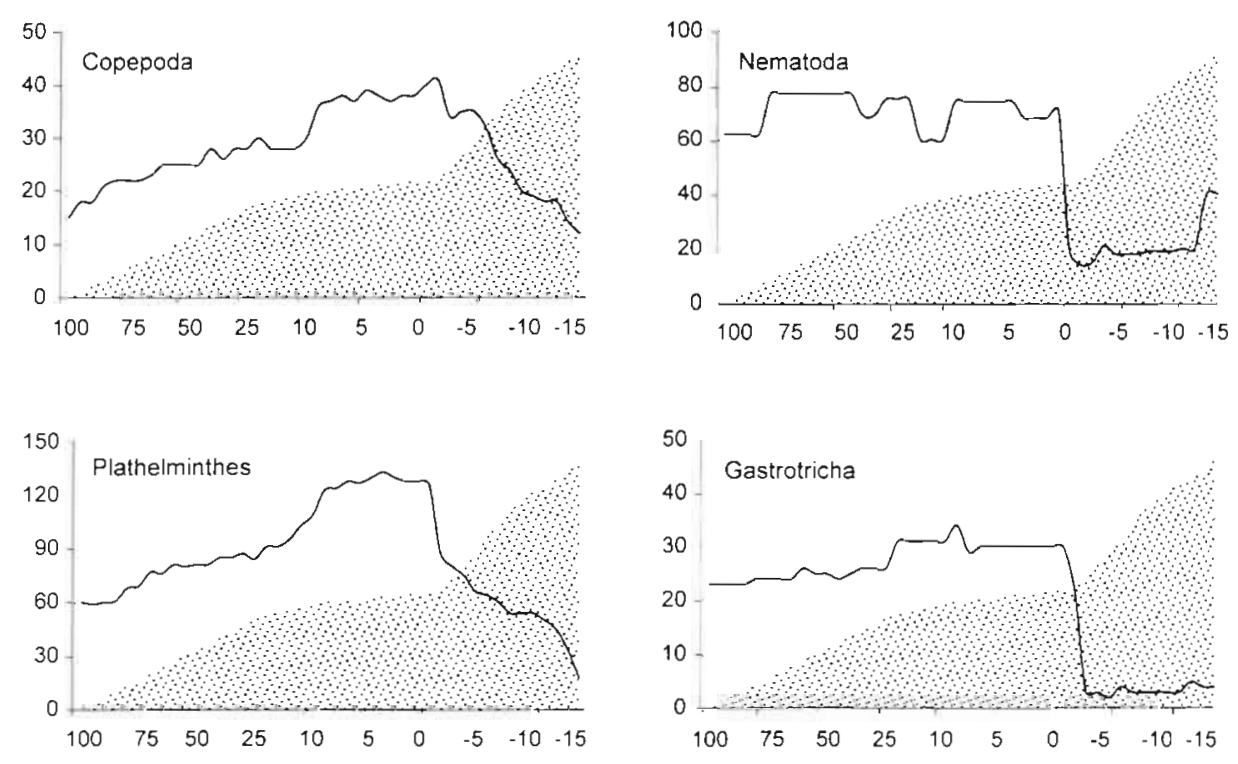

Fig. 4. Species richness of 4 major taxa of the interstitial fauna along a transect from mean high to spring low tide level. See also legend to Fig. 3 

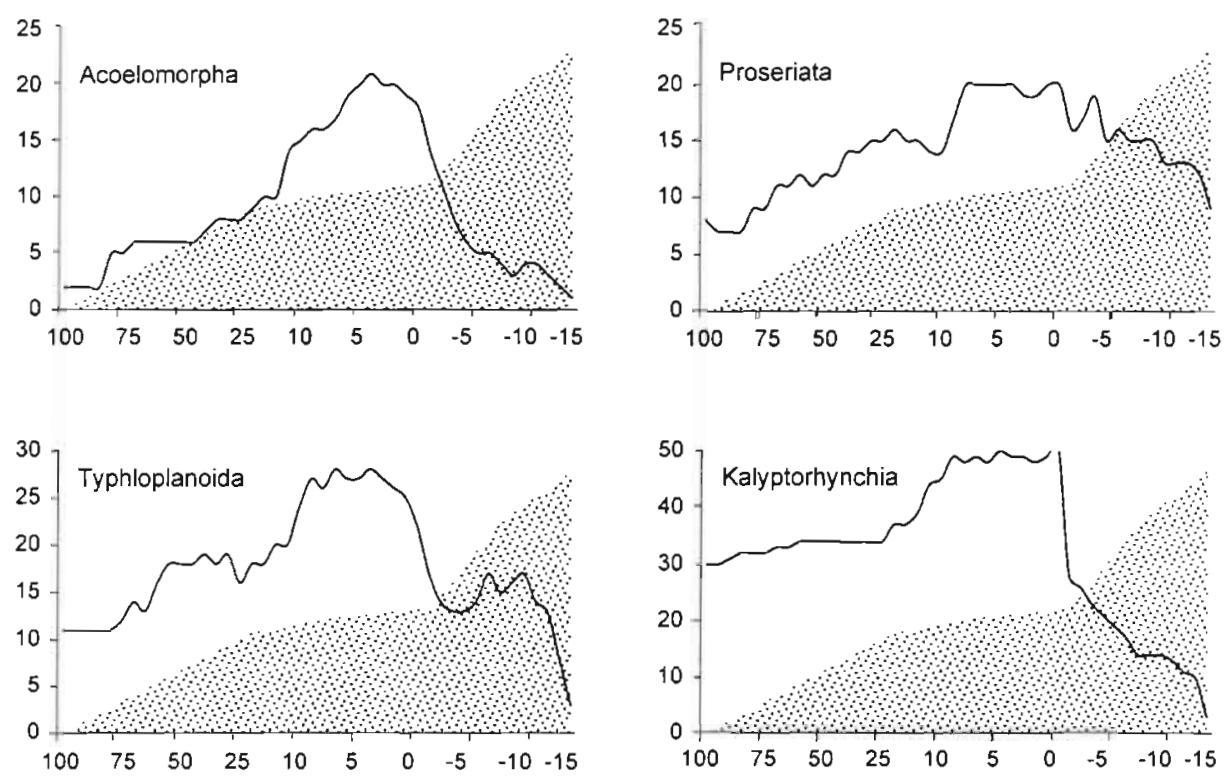

Fig. 5. Species richness of 4 major groups of the free-living Plathelminthes along a transect from mean high to spring low tide level. See also legend to Fig. 3

because of the intermediacy of the beach on a gradient from very sheltered to very exposed (Schmidt 1968, Armonies \& Hellwig-Armonies 1987). A further advantage for the interstitial fauna may be a relatively coarse grained sand in a rather sheltered position, a deviation caused by local geology. In comparison, the terrestrial soil fauna of a temperate forest is estimated by Irmler (1995) to have 1000 and by Schaefer (1990) to have 1685 species.

In a review on plathelminth diversity around the island of Sylt, Reise (1988) recorded a total of 435 species. In addition to the 207 found at the present study site, this number includes plathelminths from more sheltered as well as from more exposed beaches, from salt marshes, various intertidal sand and mudflats as well as deep tidal channels and inlets. Assuming in analogy to the plathelminths a ratio of about 2 for the species number of a single site to the entire habitat range of a locality also for the other major taxa of the interstitial fauna, there may be about 1600 species around the island of Sylt.

The validity of species numbers for comparisons may be questioned because this parameter increases with sampling effort. However, at the studied beach it was one of the aims to describe all species present, and most investigators did not stop sampling until new species became exceedingly rare. Re-investigations of some major taxa some $15 \mathrm{yr}$ after the first surveys were completed, revealed almost no additional species (Armonies \& Hellwig-Armonies 1987. Potel \& Reise 1987, Wellner \& Reise 1989). To our knowledge, there are no

other studies of the interstitial fauna of
Fig. 6. Sørensen similarity index of the species composition along the transect from mean high to spring low tide level. Similarity was calculated between a selected site and each of the other sites of the transect. Five sites $(60,10,5,-5$, and $-10 \mathrm{~m}$ from the bend, indicated by vertical lines) were selected as a starting point. In all 5 cases, similarity initially shows a gradual decrease with increasing horizontal distance of the sites compared. However, the rate of change always accelerates near the bend, despite of the narrow spacing of sites ( $1 \mathrm{~m}$ distance) in that region. Shading indicates the profile of the shore 
a marine beach which are as complete as the one presented here.

\section{Spatial pattern of diversity}

The benthic macrofauna increased in species richness in downshore direction, which is in line with many other surveys reviewed by Brown \& McLachlan (1990). This may be explained with a direct dependence of feeding activity in most macrofaunal species on tidal submergence. The interstitial fauna showed a different pattern at the studied beach. Highest species richness was encountered at a gently sloping terrace close to mid tide level. As an explanation we propose that interstitial species are faced with 2 gradients at the beach, a physical-horizontal and a chemical-vertical gradient. Horizontally, the beach is most benign at low tide level where time of submergence is long and sediment stability high (Schmidt 1968, Riedl \& McMahan 1972). Vertically, limitations result when oxygen supply is lower than oxygen demand (Fenchel 1978). Where this is the case, the sediment turns black and high sulfide concentrations restrict the occurrence of most interstitial organisms (Reise \& Ax 1979). At the beach face, the oxygenated vertical range may exceed $1 \mathrm{ml}$, while at the sand flat this may be even $<1 \mathrm{~cm}$.

Assuming a similar importance of the horizontal and the vertical gradient, optimum conditions are expected to occur somewhere around the middle of the beach. The terrace is just below the water table outcrops of the beach face, and thus remains saturated with water throughout the tidal cycle. It is affected by reflected waves, which prevent accumulations of silt and organic particles and push oxygen into the sediment. A black sulfide layer rarely develops in this zone (i.e. Ehlers 1973, Hartwig 1973a, Hoxhold 1974, Faubel 1976c).

The shape of the species richness curve between the tide marks is asymmetric, with a small and gradual decline towards low tide line and a threshold decline at the bend between the gentle and the steep slope of the beach. The threshold decline and change in species composition may be explained by a switch from dissipative to reflective conditions at this bend, where the steep slope has a much lower physical stability than the gently sloping terrace and the flat.

The combination of horizontal and vertical gradients may generate a complex spatial matrix of living conditions (Fenchel et al. 1967). The evolutionary result may not be many specialized species because conditions vary over time, disturbances are not rare, and the animals are able to move about. The observed high species number in the beach terrace conforms well with Huston's dynamic equilibrium hypothesis which pre- dicts maximum species richness under conditions of intermediate disturbance frequency and at intermediate rate of competitive displacement (Huston 1979). In this context it is important to recall, that interstitial organisms are small and therefore the number of gametes produced at any time cannot be high (Giere 1993). This may be compensated for by permanent reproduction. However, Ax (1977) showed that this is not generally the case. Out of 74 species of free-living Plathelminthes at the investigated beach, $60 \%$ reproduced only once and $15 \%$ twice a year. Thus, many species of the interstitial fauna cannot have high population growth rates and thus the ability to outcompete others is rather limited.

The absence of pelagic larvae and thus of rapid widespread dispersal implies, on an evolutionary time scale, ample possibilities for founder effects and genetic drift in small populations, generating a high number of species in a habitat which persisted essentially unchanged since the beginning of metazoan life. In conclusion, it is the long history of a structurally complex beach habitat which may explain its high species richness of the interstitial fauna. This community may have a high functional redundancy with many microbivores, algivores and carnivores readily replacing each other and thereby practicing a high degree of resilience.

Acknowledgements. We thank all investigators who once probed this beach for allowing the authors to grow like epibionts on their shoulders and to summarize their diligent work. We also thank 3 unknown referees for their highly useful comments. This is Alfred Wegener Institute Publication No. 1727.

\section{LITERATURE CITED}

Armonies W, Hellwig-Armonies M (1987) Synoptic patterns of meiofaunal and macrofaunal abundances and specific composition in littoral sediments. Helgol Meersunters 41: $83-111$

Ax P (1966) Die Bedeutung der interstitiellen Sandfauna für allgemeine Probleme der Systematik, Ökologie und Biologie. Veröff Inst Meeresforsch Bremerhaven (Suppl) 2: $15-66$

Ax P (1969) Populationsdynamik, Lebenszyklen und Fortpflanzungsbiologie der Mikrofauna des Meeressandes. Verhandl Dt Zool Ges Innsbruck 65-113

Ax P (1970) Neue Pogaina-Arten (Turbellaria, Dalyellioida) mit Zooxanthellen aus dem Mesopsammal der Nordseeund Mittelmeerküste. Mar Biol 5:337-340

Ax P (1971) Zur Systematik und Phylogenie der Trigonostominae (Turbellaria, Neorhabdocoela). Mikrofauna Meeresboden $4: 1-84$

Ax P (1977) Life cycles of interstitial Turbellaria from the eulittoral of the North Sea. Acta Zool Fenn 154:11-20

Ax P, Ax R (1970) Das Verteilungsprinzip des subterranen Psammon am Übergang Meer-Süßwasser. Mikrofauna Meeresboden 1:4-51 
Ax P, Heller R (1970) Neue Neorhabdocoela (Turbellaria) vom Sandstrand der Nordsee-Insel Sylt. Mikrofauna Meeresboden 2:1-46

Bartsch I, Schmidt P (1979) Zur Verbreitung und Ökologie einiger Halacaridae (Acari) in Sandstränden der Ostsee (Kieler Bucht), der Nordsee (Sylt) und des Europäischen Nordmeeres (Tromsö). Mikrofauna Meeresboden 74:1-37

Blome D (1974) Zur Systematik von Nematoden aus dem Sandstrand der Nordseeinsel Sylt. Mikrofauna Meeresboden 33:1-25

Blome D (1982) Systematik der Nematoda eines Sandstrandes der Nordseeinsel Sylt. Mikrofauna Meeresboden 86: $1-194$

Blome D (1983) Ökologie der Nematoda eines Sandstrandes der Nordseeinsel Sylt. Mikrofauna Meeresboden 88:1-76

Brown AC, McLachlan A (1990) Ecology of sandy shores. Elsevier, Amsterdam

Committee on Biological Diversity in Marine Systems (1995) Understanding marine biodiversity. Natl Acad Sci, Washington, DC

Dörjes J (1968a) Die Acoela (Turbellaria) der Deutschen Nordseeküste und ein neues System der Ordnung. Z Zool Syst Evolutionsforsch 6:56-452

Dörjes J (1968b) Zur Ökologie der Acoela (Turbellaria) in der Deutschen Bucht. Helgol Wiss Meeresunters 18:78-115

Ehlers U (1972) Systematisch-phylogenetische Untersuchungen an der Familie Solenopharyngidae (Turbellaria, Neorhabdocoela). Mikrofauna Meeresboden 11:1-78

Ehlers U (1973) Zur Populationsstruktur interstitieller Typhloplanoida und Dalyellioida (Turbellaria, Neorhabdocoela). Mikrofauna Meeresboden 19:1-105

Ehlers U (1974) Interstitielle Typhloplanoida (Turbellaria) aus dem Litoral der Nordseeinsel Sylt. Mikrofauna Meeresboden 49:1-102

Ehlers U, Müller B, Franke M (1994) Three new species of the Typhloplanoida (Plathelminthes, Rhabdocoela) from the island of Sylt (North Sea). Microfauna marina 9:313-332

Faubel A (1974a) Die Acoela (Turbellaria) eines Sandstrandes der Nordseeinsel Sylt. Mikrofauna Meeresboden 32:1-58

Faubel A (1974b) Macrostomida (Turbellaria) von einem Sandstrand der Nordseeinsel Sylt. Mikrofauna Meeresboden 45:1-32

Faubel A (1976a) Eine neue Art der Gattung Retronectes (Turbellaria, Catenulida) aus dem Küstengrundwasser der Nordseeinsel Sylt. Zool Scr 5:217-220

Faubel A (1976b) Interstitielle Acoela (Turbellaria) aus dem Litoral der nordfriesischen Inseln Sylt und Amrum (Nordsee). Mitt Hamburg Zool Mus Inst 73:17-56

Faubel A (1976c) Populationsdynamik und Lebenszyklen interstitieller Acoela und Macrostomida (Turbellaria). Mikrofauna Meeresboden 56:1-107

Fenchel TM (1978) The ecology of micro- and meiobenthos. Annu Rev Ecol Syst 9:99-121

Fenchel TM, Jansson BO, Thun WJ (1967) Vertical and horizontal distribution of the metazoan microfauna and of some physical factors in a sandy beach in the northern part of Øresund. Ophelia 4:227-243

Giere O (1993) Meiobenthology. Springer, Berlin

Grassle JF, Maciolek NJ (1992) Deep-sea species richness: regional and local diversity estimates from quantitative bottom samples. Am Nat 139:313-341

Hartwig E (1973a) Die Ciliaten des Gezeiten-Sandstrandes der Nordseeinsel Sylt. II. Ökologie. Mikrofauna Meeresboden 21:1-171

Hartwig E (1973b) Die Ciliaten des Gezeiten-Sandstrandes der Nordseeinsel Sylt. I. Systematik. Mikrofauna Meeresboden 18:1-69
Higgins R, Thiel $H$ (eds) (1988) Introduction to the study of meiofauna. Smithsonian Inst Press, Washington, DC

Hoxhold S (1974) Populationsstruktur und Abundanzdynamik interstitieller Kalyptorhynchia (Turbellaria, Neorhabdocoela). Mikrofauna Meeresboden 41:1-134

Huston M (1979) A general hypothesis of species diversity. Am Nat 113:81-101

Irmler U (1995) Die Stellung der Bodenfauna im Stoffhaushalt schleswig-holsteinischer Wälder. Faun-Ökol Mitt Suppl 18:1-200

Kossmagk-Stephan K (1983) Marine Oligochaeta from a sandy beach of the island of Sylt (North Sea) with description of four new enchytraeid species. Mikrofauna Meeresboden 89:1-28

Martens PM, Curini-Galletti MC, Puccinelli, I (1989) On the morphology and karyology of the genus Archilopsis (Meixner) (Plathelminthes, Proseriata). Hydrobiologia 175: $237-256$

May RM (1988) How many species are there on earth? Science 241:1441-1449

May RM (1992) Bottoms up for the ocean. Nature 357: $278-279$

Meineke T, Westheide W (1979) Gezeitenabhängige Wanderungen der Interstitialfauna in einem Sandstrand der Insel Sylt (Nordsee). Mikrofauna Meeresboden 75:1-36

Menn I, Armonies W (1999) Predatory Promesostoma species (Plathelminthes, Rhabdocoela) in the Wadden Sea. J Sea Res 41:309-320

Mielke W (1973) Zwei neue Harpacticoidea (Crustacea) aus dem Eulitoral der Nordseeinsel Sylt. Mikrofauna Meeresboden 17:1-14

Mielke W (1975) Systematik der Copepoda eines Sandstrandes der Nordseeinsel Sylt. Mikrofauna Meeresboden 52: $1-134$

Mielke W (1976) Ökologie der Copepoda eines Sandstrandes der Nordseeinsel Sylt. Mikrofauna Meeresboden 59:1-86

Mock H (1978) Ototyphlonemertes pallida (Keferstein, 1862) Mikrofauna Meeresboden 67:1-14

Mock H (1979) Chaetonotoidea (Gastrotricha) der Nordseeinsel Sylt. Mikrofauna Meeresboden 78:1-107

Mock H (1981a) Zur Morphologie von Prostomatella arenicola (Hoplonemertini, Monostilifera). Helgol Meeresunters 34 491-496

Mock H (1981b) Zur Kenntnis von Diurodrilus subterraneus (Polychaeta, Dinophillidae) aus dem Sandhang der Nordseeinsel Sylt. Helgol Meeresunters 43:329-335

Müller U, Ax P (1971) Gnathostomulida von der Nordseeinsel Sylt mit Beobachtungen zur Lebensweise und Entwicklung von Gnathostomula paradoxa Ax. Mikrofauna Meeresboden $9: 4-41$

Noldt U, Reise K (1987) Morphology and ecology of the kalyptorhynch Typhlopolycystis rubra (Plathelminthes), an inmate of lugworm burrows in the Wadden Sea. Helgol Meeresunters 41:185-199

Pawlak R (1969) Zur Systematik und Ökologie (Lebenszyklen, Populationsdynamik) der Turbellarien Gattung Paromalostomum. Helgol Wiss Meeresunters 19:417-454

Potel P, Reise K (1987) Gastrotricha Macrodasyoida of intertidal and subtidal sandy sediments in the northern Wad den Sea. Microfauna Mar 3:363-376

Reise K (1984) Free-living Platyhelminthes (Turbellaria) of a marine sand flat: an ecological study. Microfauna Mar $1: 1-62$

Reise K (1987) Spatial niches and long-term performance in meiobenthic Plathelminthes of an intertidal lugworm flat Mar Ecol Prog Ser 38:1-11

Reise K (1988) Plathelminth diversity in littoral sediments 
around the island of Sylt in the North Sea. Prog Zool 36 $469-480$

Reise K, Ax P (1979) A meiofaunal 'thiobios' limited to the anaerobic sulfide system of marine sand does not exist. Mar Biol 54:225-237

Riedl RJ, McMahan R (1972) Hydrodynamic patterns in lotic intertidal sands and their bioclimatological implications. Mar Biol 13:179-209

Schaefer M (1990) The soil fauna of a beech forest on limestone: trophic structure and energy budget. Oecologia 82 $128-136$

Scherer B (1985) Annual dynamics of a meiofauna community from the 'sulfide layer' of a North Sea sand flat. Microfauna Mar 2:117-162

Schilke K (1970) Kalyptorhynchia (Turbellaria) aus dem Eulitoral der deutschen Nordseeküste. Helgol Wiss Meeresunters 21:143-265

Schmidt P (1968) Die quantitative Verteilung und Populationsdynamik des Mesopsammons am Gezeiten-Sandstrand der Nordseeinsel Sylt. I. Faktorengefüge und biologische Gliederung des Lebensraumes. Int Rev Ges Hydrobiol 53:723-779

Schmidt P (1969) Die quantitative Verteilung und Populationsdynamik des Mesopsammons am Gezeiten-Sandstrand der Nordseeinsel Sylt. II. Quantitative Verteilung und Populationsdynamik einzelner Arten. Int Rev Ges Hydrobiol 54:95-174

Schmidt P (1970) Zonation of the interstitial polychaete Sty gocapitella subterranea (Stygocapitellidae) in European sandy beaches. Mar Biol 7:319-323

Schmidt P. Teuchert G (1969) Quantitative Untersuchungen zur Ökologie der Gastrotrichen im Gezeiten-Sandstrand der Insel Sylt. Mar Biol 4:4-23

Snelgrove PVR and 10 others (1997) The importance of marine sediment biodiversity in ecosystern processes Ambio 26:578-583

Snelgrove PVR (1999) Getting to the bottom of marine biodiversity: sedimentary habitats. BioScience 49:129-138

Sopott B (1972) Systematik und Ökologie von Proseriaten (Turbellaria) der deutschen Nordseeküste. Mikrofauna Meeresboden 13:1-72

Sopott B (1973) Jahreszeitliche Verteilung und Lebenszyklen der Proseriata (Turbellaria) eines Sandstrandes der Nordseeinsel Sylt. Mikrofauna Meeresboden 15:1-106

Editorial responsibility: Otto Kinne (Editor),

Oldendorf/Luhe, Germany
Sopott-Ehlers B (1992) Coelogynopora faenofurca nov, spec (Proseriata, Plathelminthes) aus Wohnröhren des Polychaeten Arenicola marina. Microfauna Mar 7:185-190

Tzschaschel G (1979) Marine Rotatoria aus dem Interstitial der Nordseeinsel Sylt. Mikrofauna Meeresboden 71:1-64

Tzschaschel G (1980) Verteilung, Abundanzdynamik und Biologie mariner interstitieller Rotatoria. Mikrofauna Meeresboden 81:1-56

Uhlig G (1964) Eine einfache Methode zur Extraktion der vagilen mesopsammalen Mikrofauna. Helgol Wiss Meeresunters $11: 178-185$

Uhlig G, Thiel H, Gray J (1973) The quantitative separation of meiofauna. Helgol Wiss Meeresunters 25:173-195

Wellner G, Reise K (1989) Plathelminth assemblages from an exposed and a sheltered beach of the island of Sylt in the North Sea. Microfauna Mar 5:277-294

Westheide W (1965) Parapodrilus psammophilus nov. gen. nov. spec., eine neue Polychaeten-Gattung aus dem Mesopsammal der Nordsee. Helgol Wiss Meeresunters 12: $207-213$

Westheide W (1966) Zur Polychaetenfauna des Eulitorals der Nordseeinsel Sylt. Helgol Wiss Meeresunters 13:203-209

Westheide W (1967a) Die Gattung Trilobodrilus (Archiannelida, Polychaeta) von der deutschen Nordseeküste. Helgol Wiss Meeresunters 16:207-215

Westheide W (1967b) Monographie der Gattungen Hesionides Friedrich und Microphthalmus Mecznikow (Polychaeta, Hesionidae). Ein Beitrag zur Organisation und Biologie psammobionter Polychaeten. Z Morph Tiere 61: $1-159$

Westheide W (1968) Zur quantitativen Verteilung von Bakterien und Hefen in einem Gezeitenstrand der Nordseeküste. Mar Biol 1:336-347

Westheide W (1991) The meiofauna of the Gálapagos. A review. In: James MJ (ed) Gálapagos marine invertebrates. Taxonomy, biogeography, and evolution in Darwin's islands. Plenum Press, New York, p 37-73

Wetzel MA (1997) Gemeinschaftsstruktur der Nematodenfauna in Sauerstoff/Sulfidgradienten um ausgesuchte Makrofaunabauten im Watt. Dissertation, Univ Hamburg

Wetzel MA, Jensen P, Giere O (1995) Oxygen/sulfide regime and nematode fauna associated with Arenicola marina burrows: new insights in the thiobios case. Mar Biol 124: $301-312$

Submitted: March 16, 1999; Accepted: July 13, 1999 Proofs received from author(s): December 13, 1999 